\title{
PENGARUH KEPEMIMPINAN TRANSFORMASIONAL KEPALA SEKOLAH, PELAKSANAAN MBS, DAN PELAKSANAAN TU TERHADAP KUALITAS PENDIDIKAN SD/MI DEPOK SLEMAN
}

\author{
Wahyudi, Heri Retnowati \\ SDN Condongcatur, Universitas Negeri Yogyakarta \\ yudhi_yunamm@yahoo.co.id, retnawati_heriuny@yahoo.co.id
}

\begin{abstract}
Abstrak
Penelitian ini bertujuan untuk mengetahui pengaruh kepemimpinan transformasional kepala sekolah, pelaksanaan Manajemen Berbasis Sekolah, pelaksanaan tugas tata usaha sekolah secara bersama-sama maupun parsial terhadap kualitas pendidikan SD/MI di Kecamatan Depok Kabupaten Sleman. Penelitian ini menggunakan pendekatan kuantitatif dengan jenis penelitian korelasional. Populasi penelitian adalah seluruh SD/MI baik negeri maupun swasta di Kecamatan Depok Kabupaten Sleman. Pengumpulan data dilakukan dengan memberikan angket kuesioner para guru dan petugas tata usaha sekolah pada SD/MI di kecamatan Depok. Teknik analisis data yang digunakan adalah regresi berganda dengan taraf signifikansi 0,05. Pengujian dalam penelitian ini menggunakan bantuan program SPSS versi 16. Dari hasil analisis regresi berganda ditemukan pengaruh yang signifikan penerapan kepemimpinan transformasional kepala sekolah, manajemen berbasis sekolah dan pelaksanaan tugas tata usaha sekolah secara bersama-sama terhadap kualitas pendidikan dengan persamaan $\left(\hat{Y}=0,174 X_{1}+0,334 X_{2}+0,477 X_{3}\right)$ dan besarnya pengaruh $56,8 \% ; F(3,39)=19,382 ; p<0,05$. Selanjutnya ditinjau dari koefisien beta ditemukan pengaruh yang tidak signifikan dari kepemimpinan transformasional kepala sekolah terhadap kualitas pendidikan dengan persamaan $\hat{Y}=0,174 X_{1} ; p>0,05$, pengaruh penerapan manajemen berbasis sekolah terhadap kualitas pendidikan tidak signifikan dengan persamaan $\hat{Y}=0,334 \mathrm{X}_{2} ; \mathrm{p}>0,05$, sedangkan pelaksanaan tugas tata usaha berpengaruh secara signifikan dengan persamaan $\hat{Y}=0,477 \mathrm{X}_{3} ; \mathrm{p}<0,05$ terhadap kualitas pendidikan $\mathrm{SD} / \mathrm{MI}$ di kecamatan Depok kabupaten Sleman. Kepemimpinan transformasional kepala sekolah dan penerapan manajemen berbasis sekolah tidak memiliki hubungan yang signifikan kemungkinan disebabkan beberapa responden outlier, data pokok atau tanggapan dari peserta penelitian yang tampaknya berada di luar jangkauan sebagian besar data.
\end{abstract}

Kata kunci: kepemimpinan transformasional kepala sekolah, manajemen berbasis sekolah, tugas tata usaha, kualitas pendidikan

\section{THE EFFECTS OF PRINCIPAL'S TRANSFORMATIONAL LEADERSHIP, MBS APPLICATION, AND THE IMPLEMENTATION OF ADMINISTRATIVE TASK ON SCHOOL EDUCATION QUALITY OF SD/MI IN THE SUB-DISTRICT DEPOK, SLEMAN}

\begin{abstract}
This study aimed to reveal the effect of principals' transformational leadership, the implementation of schoolbased management, and the implementation of administrative tasks jointly or partially on educational quality of SD/MI in sub-district Depok. This was a correlational research using quantitative approach. The population was all SD/MI both public and private in the sub-district Depok, Sleman. Data collection was conducted by giving questionnaires to teachers and administrative staff in the sub-district Depok. The data analysis technique used is linear regression and multiple regression with a significance level of 0.05. All tests in this study used SPSS version 16. From the results of multiple regression analysis was found a significant effect of principal transformational leadership, school-based management application, and the implementation of administrative tasks simultaneously on the school Education Quality with equality $\left(\hat{Y}=0.174 X_{1}+0.334 X_{2}+0,477 X_{3}\right)$ and the influence of $56.8 \% ; F(3.39)=19.382 ; p<0.05$. Hereinafter review of the beta coefficients was found effect the principals' transformational leadership on the school Education Quality does not have a significant relationship with equality $\hat{Y}=0.174 X_{1} ; p>0.05$, the effect school-based management application does not have a significant relationship with equality $\hat{Y}=0.334 X_{2} ; p>0.05$, the effect implementation of administrative tasks have a significant relationship with equality $\hat{Y}=0.477 X_{3} ; p<0.05$ on school education quality of SD/MI in the Subdistrict Depok, Sleman. The principals' transformational leadership and school-based management application does not have a significant relationship, because possibility some respondents are outliers, those data points or responses from research participants that seem to lie outside the range of the bulk of the data.
\end{abstract}

Keywords: principals' transformational leadership, school-based management, the implementation of administrative tasks, quality of education. 


\section{Pendahuluan}

Pendidikan akan selalu berubah seiring dengan perubahan jaman. Setiap saat pendidikan selalu menjadi fokus perhatian masyarakat berkaitan dengan suasana kehidupan dan kondisi kehidupan saat ini, serta menyangkut investasi dan kondisi kehidupan masa yang akan datang. Itulah sebabnya pendidikan senantiasa memerlukan upaya perbaikan dan peningkatan kualitas pendidikan secara optimal sejalan dengan semakin tingginya kebutuhan dan tuntunan kehidupan masyarakat.

Dalam proses pendidikan yang bermutu, akan terlibat berbagai input, seperti bahan ajar (kognitif, afektif dan psikomotorik), metodologi (bervariasi sesuai kemampuan guru), dukungan tenaga administrasi dan sarana prasarana serta sumber daya lainnya yang dapat menciptakan suasana yang kondusif untuk pembelajaran. Manajemen sekolah, pengelolaan kelas berfungsi menyinkronkan berbagai input tersebut. Antara lain menyinergikan semua komponen dalam interaksi (proses) belajar mengajar, baik antara guru, siswa dan sarana pendukung di kelas maupun di luar kelas, baik konteks kurikuler maupun ekstrakurikuler, baik dalam lingkup subtansi yang akademis maupun non akademis dalam suasana yang mendukung proses pembelajaran.

Pendidikan yang berkualitas dan bermutu tercermin pada prestasi yang dicapai oleh sekolah pada setiap kurun waktu tertentu. Prestasi yang dicapai atau hasil pendidikan (student achievement) dapat berupa hasil tes kemampuan akademis (ulangan harian, ujian semester atau ujian nasional). Dapat pula prestasi di bidang lain seperti prestasi di suatu cabang olahraga, seni atau keterampilan tambahan tertentu. Bahkan prestasi sekolah dapat berupa kondisi yang tidak dapat dipegang intangible) seperti suasana keakraban, ketertiban, kedisiplinan, saling menghormati, kebersihan, dan lain-lain.

Permendiknas nomor 24 tahun 2008 tertanggal 11 Juni 2008 tentang Standar Tenaga Administrasi Sekolah/Madrasah di jenjang pendidikan dasar dan menengah, pasal 3 menyebutkan bahwa penyelenggara sekolah/madrasah wajib menerapkan standar tenaga administrasi sekolah/madrasah, selambat-lambat 5 (lima) tahun setelah ditetapkan. Secara umum kondisi tenaga kependidikan SD/MI di Kecamatan Depok Kabupaten Sleman pada saat ini belum memenuhi persyaratan minimal sesuai ketentuan tersebut. Memang dalam peraturan memberi kelonggaran kepada penyelenggara sekolah/madrasah untuk menetapkan perangkapan jabatan apabila dikehendaki namun hal ini menjadikan permasalahan tersendiri.

Keberadaan tenaga kependidikan di SD/MI Kecamatan Depok perlu mendapat perhatian yang lebih serius agar pelaksanaan tugas pokok dan fungsi tenaga kependidikan tersebut berjalan semestinya. Pelaksanaan tugas administrasi sekolah yang selama ini dibebankan pada Kepala Sekolah dan Guru sudah waktunya ditangani pegawai khusus sesuai bidangnya. Perangkapan jabatan guru sebagai petugas tata usaha sekolah; tugas sebagai bendahara sekolah, tugas sebagai pustakawan, tugas sebagai pengelola barang dan atau sebagai administrator sekolah, dapat mengganggu pelaksanaan tugas pokok dan fungsi guru dalam melayani peserta didik menjadi tidak maksimal sehingga dimungkinkan menurunkan kualitas pendidikan di sekolah.

Untuk mempertahankan pelayanan pendidikan yang memenuhi harapan semua pelanggan (peserta didik, orang tua siswa, dan masyarakat) sekolah harus berusaha mengangkat pegawai baru terutama tenaga tata usaha (tenaga honorer). Dengan pengangkatan pegawai baru tersebut tentu berdampak pada menyusutnya kuantitas dana pendidikan yang diterima oleh sekolah. Sumber pendanaan pendidikan di sekolah hanya bersumber dari Bantuan Operasional Sekolah (BOS). Dana pendidikan yang diterima dari pemerintah yang berasal dari BOS oleh masing-masing sekolah pada umumnya hanya cukup untuk memenuhi biaya operasional sekolah. Dengan demikian perlunya sumber dana baru untuk pengangkatan tenaga kependidikan 
baik dari pemerintah maupun dari masyarakat, komite, pengusaha, maupun dari orang tua murid yang mampu, sehingga di sekolah tersedia pegawai yang khusus menanagani administrasi sekolah.

Dalam Undang-Undang Republik Indonesia Nomor 20 Tahun 2003 tentang Sisdiknas pada pasal 51 ayat 1 berbunyi "Pengelolaan satuan pendidikan anak usia dini, pendidikan dasar, dan pendidikan menengah dilaksanakan berdasarkan standar pelayanan minimal dengan prinsip manajemen berbasis sekolah/madrasah". Manajemen berbasis sekolah merupakan suatu penawaran bagi sekolah untuk menyediakan proses pendidikan yang lebih baik dan lebih memadahi bagi para peserta didik. Otonomi dalam pengelolaan pendidikan merupakan potensi bagi sekolah untuk meningkatkan kinerja para pendidik dan tenaga kependidikan dan memberikan peluang partisipasi langsung masyarakat terhadap pendidikan. Untuk meningkatkan kualitas pendidikan sedapat mungkin segala keputusan yang menyangkut layanan proses pendidikan di sekolah seharusnya dibuat oleh kepala sekolah dan para pendidik dan tenaga kependidikan, mengingat mereka yang bertanggung jawab secara langsung dari tuntutan masyarakat terhadap mutu pendidikan di sekolah.

Dalam Peraturan Menteri Pendidikan Nasional Nomor 13 tahun 2007 tanggal 17 April 2007 Kepala Sekolah dalam tugas manajerial harus mampu mengelola perubahan dan pengembangan sekolah/madrasah menuju organisasi pembelajar yang efektif. Kepemimpinan kepala sekolah efektif dalam mendukung terwujudnya mutu pendidikan di sekolah maka perlu mendapat dukungan dari berbagai pihak, sehingga nantinya tepat dalam pemberdayaan sumberdaya yang ada di sekolah. Pemberdayaan tersebut dimaksud untuk meningkatkan kemampuan secara fungsional, dengan harapan kepala sekolah mampu memainkan perannya sesuai dengan tugas, wewenang dan tanggung jawabnya.

\section{Kualitas Pendidikan}

Pendidikan yang berkualitas salah satu indikatornya adalah kemampuan lembaga dan sistem pendidikan dalam memberdayakan sumber-sumber pendidikan sesuai dengan tugas pokok dan fungsi sumberdaya yang dimilikinya untuk meningkatkan kualitas layanan yang sesuai dengan harapan atau tujuan pendidikan melalui proses pendidikan yang efektif. Sallis (1993, pp.21-25), menyebutkan bahwa mutu atau kualitas adalah "a absolute and a relative concept". Kualitas menurut konsep absolute adalah "the highest possible standart which can not be surpassed". Dalam konsep relative, produk atau jasa dianggap berkualitas jika barang atau jasa memenuhi standar yang ditetapkan. Menurut konsep ini, mutu memiliki dua aspek, yaitu (a) measuring up to specification artinya berdasarkan spesifikasi yang telah ditetapkan oleh produsen; dan (b) meeting customer requirements artinya memenuhi keperluan pelanggan.

Menurut pendapat Mardapi (2012, p.3) bahwa usaha peningkatan kualitas pendidikan harus dilakukan terus menerus dan berkesinambungan. Usaha peningkatan kualitas pendidikan di sekolah dapat dilakukan dengan peningkatan kualitas pembelajaran dan kualitas sistem penilaian. Meningkatnya kualitas pembelajaran yang dilaksanakan di berbagai jenjang pendidikan akan mampu meningkatkan kualitas pendidikan. Usaha peningkatan kualitas pendidikan akan berlangsung dengan baik manakala didukung oleh kompetensi dan kemauan para pengelola pendidikan. Untuk melakukan perbaikan secara terusmenerus menuju kearah yang lebih baik sangat diperlukan kesiapan pengelola sekolah yang berkompeten dan perencanaan yang mantap.

Dengan demikian sesuatu yang bermutu harus memiliki dua standar mutu. Pertama, mutu sesungguhnya yaitu penyesuian diri terhadap spesifikasi, sesuai dengan tujuan dan manfaat yang telah ditentukan sebelumnya. Artinya, komitmen terhadap apa yang ditetapkan untuk bisa 
direalisasikan, maka hal demikian secara bertahap akan mencapai mutu yang diinginkan. Kedua, mutu persepsi yaitu sesuatu harus dibuktikan dengan terpenuhinya tuntutan dan kebutuhan pengguna jasa atau melampui dan memuaskan kebutuhan pelanggan. Dengan memahami keinginan pelanggan, maka mutu akan bisa diupayakan bahkan melampaui kepuasan pelanggan sehingga akan memberikan kepercayaan kepada lembaga tersebut.

Pendidikan di sekolah dikatakan berkualitas apabila dapat menghasilkan lulusan yang memiliki kemampuan dasar untuk belajar. Sekolah dapat memberdayakan sumber-sumber pendidikan secara optimal, sehingga dapat menciptakan pembelajaran yang baik dan kondusif. Usman (2011, p.513), berpendapat bahwa mutu dibidang pendidikan meliputi input, proses, output dan outcome. Kualitas dalam layanan pendidikan dapat dikelompokkan dalam kualitas input, kualitas proses dan kualitas output. Kualitas proses pendidikan ditentukan dengan metode, suasana, dan kemampuan melaksanakan manajemen proses pembelajaran itu sendiri. Kualitas proses pendidikan akan ditentukan dengan seberapa besar kemampuan memberdayakan sumberdaya yang ada untuk siswa belajar secara produktif. Manajemen sekolah, dukungan kelas berfungsi menyinkronkan berbagai input tersebut atau mensinergikan semua komponen dalam interaksi (proses) belajar mengajar baik antara guru, siswa dan sarana pendukung di kelas maupun di luar kelas; baik konteks kurikuler maupun ekstra-kurikuler, baik dalam lingkup subtansi yang akademis maupun yang non-akademis dalam suasana yang mendukung proses pembelajaran. Sedangkan Output dinyatakan bermutu jika hasil belajar akademik siswa tinggi. Salah satu indikasinya terlihat dalam laporan nilai prestasi siswa setiap akhir tahun ajaran.

Kualitas dalam pendidikan adalah sangat penting karena dapat membantu proses pembentukan kemampuan anakanak dalam pembelajaran seumur hidup. Kualitas dalam layanan pendidikan dapat dikelompokkan dalam kualitas input, kualitas proses dan kualitas output pendidikan. Kualitas pendidikan dapat tercermin dari kemampuan sekolah dalam memberdayakan segala sumber belajar untuk kualitas hasil belajar seperti kualitas lulusan yang dapat melanjutkan pendidikan.

\section{Kepemimpinan transformasional}

Kepemimpinan transformasional sangat diperlukan pada organisasi sekolah dengan harapkan berpengaruh terhadap sekolah yang kekurangan sumber daya. Kepala sekolah yang kurang memperhatikan organisasi sekolahnya, kurang menyediakan sumberdaya yang dibutuhkan sekolah termasuk mengusahakan tenaga kependidikan, kurang memotivasi para pendidik, bisa dikatakan kurang berperan sebagai agen perubahan, sehingga akan berpengaruh pada layanan kualitas pendidikan untuk meningkatkan mutu pendidikan di sekolah.

Sesuai pendapat Bass \& Aviola dalam Komariah \& Triatna (2010, pp. 79-80), terdapat empat komponen kepemimpinan transformasional tersebut, sebagai berikut.

\section{Idealized influence}

Pengaruh yang diidealkan, memiliki visi dan tujuan yang jelas, para pemimpin tersebut mampu menghasilkan rasa hormat dan rasa percaya pada bawahan. Idealized Influence mengandung makna saling berbagi resiko, melalui pertimbangan atas kebutuhan yang dipimpin di atas kebutuhan pribadi, serta perilaku moral dan etis.

\section{Inspirational motivation}

Aspek ini tercermin dalam perilaku yang senantiasa menyediakan tantangan dan makna atas pekerjaan orang-orang yang dipimpin, dan perilaku yang mampu mendemonstrasikan komitmen terhadap sasaran organisasi. Semangat ini dibangkitkan melalui antusiasme dan optimisme staf.

\section{Intellectual stimulation}

Stimulasi intelektual direfleksikan oleh pemimpin yang selalu mendemonstrasikan tipe kepemimpinan senantiasa 
menggali ide-ide baru dan solusi secara nalar yang kreatif dari orang-orang yang dipimpinnya. Ia juga selalu mendorong pendekatan baru dalam melakukan pekerjaan.

\section{Individualized consideration}

Pemimpin yang selalu mendengarkan dengan penuh perhatian, dan memberikan perhatian khusus kepada kebutuhan prestasi dan kebutuhan dari orangorang yang dipimpinnya.

Uraian tersebut memberikan gambaran bahwa kepemimpinan transformasional adalah kepemimpinan yang berani melakukan perubahan menuju tingkat produktivitas organisasi yang lebih tinggi, yang mampu membangkitkan semangat dan motivasi pengikutnya, dan mampu menciptakan budaya organisasi yang positif.

Indikator lain kepemimpinan transformasional sejalan dengan apa yang ditawarkan Bernard Bass dalam Steven Covey (2007,p.4)“Defined transformational leadership in terms of how the leader affects followers, who are intended to trust, admire and respect the transformational leader". Dalam kepemimpinan transformasional seorang pemimpin mampu mempengaruhi pengikut, sehingga timbul kepercayaan, kekagaguman dan secara sadar para pengikut menghormatinya.

Berdasarkan uraian tersebut, maka jelaslah bahwa seorang pemimpin diikuti orang karena visinya, misi yang dirumuskannya atau sasaran kerjanya. Mereka percaya kepada kepemimpinannya karena apa yang mau dicapainya bersama dengan para pengikutnya memang baik dan jelas. Mereka memilih mengikutinya karena sang pemimpin mampu menggali apa yang secara tidak sadar telah menjadi impian mereka. Seorang pemimpin berusaha membawa pengikutnya kearah suatu idealisme, tidak hanya sekedar melakukan tugas, namun ia dapat meyakinkan pengikutnya untuk mencapai apa yang menjadi tujuan atau cita-citanya. Hal yang dilakukan pemimpin diantaranya dengan meningkatkan kesadaran para pengikut ten- tang pentingnya melaksanakan tugas dan nilai dari tugas yang telah diselesaikanya.

Jadi kepemimpinan sebagai suatu daya untuk menggerakkan orang menuju suatu tujuan atau impian tertentu. Seorang pemimpin adalah orang yang mampu menghasilkan suatu perubahan atau transformasi pada mereka yang dipimpinnya, dirinya sendiri dan sistem atau komunitas dimana mereka berada. Peendapat senada dikemukakan oleh Bernard Bass (Steven Covey, 2007, p.4) bahwa "Increasing their awareness of task importance and value. And getting them to focus first on team or organizational goals, rather than their own interests". Hal yang dilakukan pemimpin diantaranya dengan meningkatkan kesadaran para pengikut tentang pentingnya melaksanakan tugas dan nilai dari tugas yang telah diselesaikanya. Mengarahkan pada mereka untuk fokus pada tim atau tujuan organisasi, bukan untuk memenuhi kepentinganya sendiri.

Membangun kesadaran berorganisasi pada para pengikutnyapun dilakukan oleh pemimpin, yaitu dengan jalan mengembangkan rasa memiliki organisasi (sense of belonging), dan rasa bertanggung jawab (sense of responsibility), serta membangun kemauan untuk meraih prestasi yang setinggi-tingginya. Kepemimpinan transformasional mau memberikan perlindungan (mengayomi) dan menciptakan rasa aman di kalangan pengikutnya. Dan mampu menampung dan menangkap semua aspirasi dan kepentingan semua pengikutnya. Dalam hal ini pemimpin harus mau menggunakan kemampuan intelektualnya secara cerdas dalam proses pengambilan keputusan, sehingga dapat memperjuangkan kebutuhan pengikutnya.

Kepemimpinan transformasional juga selalu berusaha membawa pengikutnya kearah suatu idealisme, tidak hanya sekedar "asal jalan", namun dapat meyakinkan pengikutnya bahwa apa yang dicita-citakannya (idealisme tersebut pasti akan tercapai), sehingga pengikutnya selalu memuja-muja akan kemampuan dan keunggulan pemimpinannya. Karena pemimpin menempatkan diri sebagai agen perubahan 
(change agent). Oleh sebab itu pemimpin transformasional selalu belajar terus sepanjang hidupnya (they are life-long learner).

\section{Manajemen Berbasis Sekolah (MBS)}

Wohlstetter \& Mohrman dalam Nurkolis (2006, p.2) menyatakan bahwa Manajemen Berbasis Sekolah (MBS) merupakan suatu pendekatan untuk mendesain ulang organisasi sekolah dengan memberikan wewenang dan kekuasaan kepada partisipan sekolah pada tingkat lokal, yang meliputi kepala sekolah, guru, konselor, pengembang kurikulum, administrator, orang tua siswa, masyarakat sekitar, serta siswa untuk memajukan sekolah. Dengan kata lain, sekolah diberi kewenangan mengatur dan mengarahkan sekolah sesuai dengan potensi atau karakteristik sekolah.

Definisi senada dikemukakan oleh Mulyasa (2002,pp.11-12), diantaranya, menurut BPPN dan Bank Dunia (1999), MBS merupakan bentuk alternatif sekolah dalam program desentralisasi pendidikan, yang ditandai oleh otonomi luas di tingkat sekolah, partisipasi masyarakat dan dalam kerangka kebijakan pendidikan nasional. Pendapat lain dikemukakan oleh Depdikbud, bahwa MBS merupakan suatu penawaran bagi sekolah untuk menyediakan pendidikan yang lebih baik dan lebih memadai bagi para peserta didik.

Berdasarkan berbagai definisi dan pandangan tersebut, maka dapat disimpulkan bahwa manajemen berbasis sekolah merupakan suatu strategi peningkatan mutu pendidikan melalui pemberian kewenangan kepada sekolah untuk menyelenggarakan dan mengelola pendidikan secara mandiri sesuai dengan karakteristik dan potensi yang dimiliki sekolah. Peningkatan mutu juga diperoleh melalui kelenturan pengelolaan sekolah dan peningkatan profesionalisme guru, hal ini dikarenakan manajemen berbasis sekolah menuntut kemandirian masyarakat sekolah sehingga guru juga dituntut untuk meningkatkan kompetensinya.

Tujuan manajemen berbasis sekolah dalam memeratakan pendidikan, tampak pada tumbuhnya partisipasi dan kepeduli- an masyarakat terhadap pendidikan. Partisipasi dan kepedulian masyarakat tersebut ditunjukkan dengan adanya kesadaran dari masyarakat yang mampu untuk membantu pendanaan pendidikan di sekolah, sementara yang kurang mampu akan menjadi tanggung jawab pemerintah. Dengan demikian tujuan manajemen berbasis sekolah secara umum ialah memandirikan masyarakat sekolah untuk mengelola pendidikan di lingkup sekolahnya, dalam upaya meningkatkan efisensi, mutu serta pemerataan pendidikan.

Kepala sekolah merupakan pemimpin sekolah yang menjadi tokoh penggerak atas kegiatan-kegiatan di sekolah yang dilakukan dalam rangka pencapaian tujuan sekolah. Dengan adanya manajemen berbasis sekolah ini, kepemimpinan kepala sekolah sangat berpengaruh atas keberhasilan manajemen berbasis sekolah. Sehubungan dengan MBS Sagala (2011, p. 156), berpendapat bahwa manajemen berbasis sekolah adalah gagasan yang menempatkan kewenangan pengelolaan sekolah dalam satu keutuhan entitas sistem untuk membuat keputusan. Setiap sekolah memiliki ciri khas dalam menerapkan manajemen berbasis sekolah yang dicerminkan oleh visi, misi, tujuan, prioritas program, sasaran-sasaran yang akan dicapai, sarana dan prasarana, mutu sumber daya manusia, dukungan biaya bagi pengembang sekolah, dan dukungan stakeholders.

Peran kepala sekolah dalam manajemen berbasis sekolah juga dikemukakan oleh Wohlstetter \& Mohrman dalam Nurkolis (2006, p.122) peran kepala sekolah dalam manajemen berbasis sekolah adalah sebagai designer, motivator, fasilitator, dan laisson. Sebagai designer, kepala sekolah harus membuat rencana dengan memberikan kesempatan untuk terciptanya diskusidiskusi menyangkut isu-isu dan permasalahan di seputar sekolah dengan tim pengambilan keputusan sekolah, dengan demikian kepala sekolah harus aktif mengikuti perkembangan sekolah yang dipimpinnya, serta melakukan kerja sama dengan masyarakat sekolah sehingga kepala sekolah akan dapat menyusun rencana yang baik bagi 
kemajuan sekolah yang dipimpinnya. Sebagai motivator, kepala sekolah harus menunjukkan adanya kepercayaan, mendorong proses pengambilalihan risiko dan menyampaikan informasi serta mempermudah partisipasi berbagai pihak dalam penerapan manajemen berbasis sekolah.

Sebagai fasilitator, kepala sekolah harus mampu menyediakan segala bentuk fasilitas guna pengelolaan dan pengembangan sekolah, kepala sekolah harus mendorong proses pengembangan kemampuan seluruh staf secara terus menerus dan berkesinambungan terhadap seluruh aktivitas sekolah. kepala sekolah harus menyediakan sumber daya yang tampak seperti kebutuhan finansial, peralatan serta material lain, juga sumber daya yang tidak tampak seperti waktu dan kesempatan kepada staf untuk membantu kemajuan sekolah.

Sedangkan sebagai penghubung sekolah dengan dunia di luar sekolah, kepala sekolah harus membawa ide-ide baru dan hasil-hasil penelitian ke sekolah, terutama yang terkait dengan belajar dan pembelajaran. Kepala sekolah juga mengkomunikasikan kemajuan dan hasil-hasil yang telah dicapai di sekolah kepada stakeholders di luar sekolah.

Dengan demikian peran kepala sekolah dalam manajemen berbasis sekolah sangatlah kompleks. Pelaksanaan manajemen berbasis sekolah menuntut masyarakat sekolah untuk mandiri, termasuk kepala sekolah sebagai pimpinan, hal ini menyebabkan jumlah tugas dan tuntutan yang harus dilaksanakan oleh kepala sekolah menjadi semakin komplek.

Dalam pelaksanaan MBS terdapat beberapa prinsip-prinsip dasar. Prinsip-prinsip tersebut seperti yang diungkapkan oleh Cheng (1996, pp.45-47) yaitu: (a) principle of equifinality: many different ways to achieve goals, emphasizes flexibility; (b) principle of decentralization: problem are inevitable, should be solved at where they happen in time, look for efficiency and problem solving; (c) principle of self-managing system: self managing, actively exploitative and responsible; (d) principle of human initiative: develops internal human resources, wide participation of school members.
Prinsip manajemen berbasis sekolah menurut Cheng meliputi empat bidang yaitu: pertama prinsip kesetaraan dengan kesadaran bahwa banyak cara mencapai tujuan sekolah dan menekankan fleksibel atau menyesuaikan dengan keadaan; prinsip kedua adalah desentralisasi, yaitu tidak menyepelekan masalah yang harus diselesaikan sesuai tempat dan waktu terjadinya, mencari efisiensi dan upaya pemecahan masalah; prinsip ketiga sistem manajemen sendiri yaitu mengelola diri sendiri dengan kekuatan sendiri, mencari cara-cara baru dan bertanggungjawab; prinsip keempat adalah inisiatif manusia yaitu mengembangkan sumber daya manusia dan perluasan partisipasi warga sekolah.

Indikator keberhasilan pelaksanaan manajemen berbasis sekolah terlihat ada kemandirian yang kuat, kemitraan yang efektif, partisipasi dari masyarakat, keterbukaan yang bertanggung jawab, dan akuntabilitas yang dapat dipertanggungjawabkan oleh sekolah/madrasah. Lebih spesifik lagi yang bisa diimplementasikan sekolah dan menjadi wewenang dan tanggung jawab sekolah berkaitan langsung pada proses belajar mengajar, perencanaan, dan evaluasi program sekolah, pengelolaan kurikulum, pengelolaan ketenagaan, pengelolaan peralatan dan perlengkapan sekolah, pengelolaan keuangan sekolah, pelayanan siswa, dan hubungan sekolah dengan masyarakat, serta pengelolaan iklim sekolah. Pada akhirnya diharapkan sekolah dapat memberikan layanan pendidikan pada pelangganya menjadi lebih baik dan lebih berkualitas.

Dengan demikian dapat disimpulkan bahwa manajemen berbasis sekolah (MBS) merupakan pemberian kesempatan yang lebih luas kepada kepala sekolah dalam pengelolaan sekolah. Sekolah diberikan kewenangan yang lebih besar untuk mengelola sekolah secara mandiri sesuai dengan kondisi sekolah. Kegiatan pengelolaan sekolah, mulai dari perencanaan, pelaksanaan, sampai dengan evaluasi ditentukan oleh kepala sekolah. Agar pengelolaan sekolah berhasil baik maka kepala sekolah 
harus mampu mengembangkan sumber daya dan potensi yang dimiliki sekolah.

\section{Administrasi dalam Pendidikan}

Untuk pengelolaan sekolah tidak jauh berbeda dengan pengelolaan lembaga atau organisai yang lain. Selain adanya para guru sebagai pendidik juga sangat diperlukan tenaga administrasi sekolah. Keberadaan tenaga administrasi sekolah sangat membantu guru dalam proses belajar mengajar di sekolah. Pemeliharaan dan perawatan sarana dan prasarana, media pembelajaran, alat pelajaran, pendokumentasian surat-menyurat diperlukan orang yang ahli dalam bidang tersebut. Dengan demikian diperlukan adanya tenaga yang handal membantu kepala sekolah dalam menyelesaikan tugas administrasi di sekolah.

Dalam suatu institusi diperlukan pegawai yang berkompeten untuk melaksanakan tugas-tugasnya. Sallis (1993, p.134), memberikan berpendapat sebagai berikut :

The staff of any institution need to be seen to be competent to carry out their tasks. The quality sytem will need to detail the staff selection and recruitment process, induction, and the means by which competence and motivation are assessed, as well as the policies for career development.

Untuk memperoleh pegawai yang berkompeten dalam melaksanakan tugastugasnya pada institusi diawali dari proses seleksi dan rekrutmen pegawai. Proses rekrutmen dan seleksi diperlukan agar setelah menjadi pegawai dapat bekerja sesuai jenis pekerjaan yang harus ditangani pada lembaga atau organisai. Disamping itu diperlukan usaha untuk memotivasi mereka secara terus-menerus serta selalu diadakan evaluasi sehubungan dengan tugas dan kinerjanya.

Pada lembaga sekolah diperlukan keberadaan tata laksana pendidikan dengan istilah tenaga administrasi pendidikan atau disebut tata usaha sekolah, menurut Arikunto (2012, p.261), administrasi tata usaha adalah segenap proses kegiatan pengelolaan surat-menyurat, yang tugasnya antara lain menghimpun, menerima, mencatat, mengelola, menggandakan, mengirim dan menyimpan semua bahan keterangan yang diperlukan oleh organisasi. Administrasi pendidikan di sekolah adalah mencakup pengaturan, proses belajar-mengajar, kesiswaan, personalia, peralatan pembelajaran, gedung dan perlengkapan, keuangan serta humas atau hubungan dengan masyarakat. Pembenahan pengelolaan administrasi pendidikan di sekolah dasar harus terus diupayakan agar dapat mefasilitasi proses pendidikan.

Administrasi pendidikan merupakan segenap usaha yang melibatkan berbagai aspek untuk melakukan pengelolaan segala sumber daya pendidikan yang ditujukan dalam meningkatkan mutu pendidikan sebagai realisasi tercapai tujuan pendidikan. Peningkatan mutu pembelajaran di sekolah tidak bisa lepas dari peran pelaksanaan administrasi sekolah. Peningkatan mutu pembelajaran di sekolah merupakan bagian yang sangat penting dalam upaya peningkatan mutu pendidikan di sekolah.

\section{Metode Penelitian}

Jenis Penelitian

Penelitian ini merupakan penelitian kuantitatif. Penelitian ini berusaha untuk mengungkap kenyataan atau gejala peristiwa yang telah terjadi dan berimplikasi pada berbagai tindakan sesudahnya. Penelitian ini dilakukan dengan menggunakan metode analisis deskriptif, yaitu penelitian terhadap masalah-masalah berupa faktafakta saat ini dari suatu populasi. Tujuan dari penelitian ini adalah untuk menguji hipotesis atau menjawab pertanyaan yang berkaitan dengan keadaan sekarang ini (current status) dari subyek yang diteliti dan menggunakan metode kuantitatif untuk mencari pengaruh antar variabel yang diteliti. Peneliti ingin mendapatkan gambaran mengenai penerapan kepemimpinan transformasional, pelaksanaan tugas administrasi pendidikan, pelaksanaan manajemen berbasis sekolah dan kontribusinya terhadap layanan kualitas pendidikan di SD/MI kecamatan Depok Sleman. 
Dengan menggunakan metode deskriptif diharapkan akan diperoleh data yang hasilnya akan diolah dan dianalisis serta akhirnya ditarik sebuah kesimpulan. Kesimpulan yang dibuat akan berlaku bagi seluruh populasi yang menjadi obyek penelitian. Penelitian ditentukan atau dinyatakan dengan taraf kepercayaan (confidence level) pada pengujian yang dilakukan dengan menetapkan taraf signifikansi a $=0,05$ (5\%). Artinya tingkat kepercayaan pengujiannya adalah $95 \%$.

Tempat dan Waktu Penelitian

Penelitian ini dilakukan di Sekolah Dasar (SD) dan Madrasah Ibtidaiyah (MI) Kecamatan Depok Kabupaten Sleman. Penelitian dilakukan selama 3 bulan yaitu pada bulan Nopember 2013 sampai dengan bulan Januari 2014.

\section{Subyek Penelitian}

Subyek penelitian adalah tenaga pendidik dan tenaga kependidikan yang bertugas di SD/MI kecamatan Depok Sleman. Pengambilan sampel menggunakan teknik secara acak (random sampling) karena dapat memberikan peluang yang sama bagi setiap unsur (anggota) populasi untuk dipilih menjadi anggota sampel, Sugiono (2013, p.122).

Pemberian angket kuesioner dilakukan terlebih dahulu dengan memohon ijin dan memohon bantuan kepada kepala sekolah sebagai seorang yang berwenang dan bertanggung jawab pada masing-masing SD/MI untuk memberikan kuesioner pada guru dan tenaga tata usaha di sekolahnya. Setiap sekolah diberikan 3 bendel angket dengan ketentuan, bilamana dalam satu sekolah ada petugas tata usaha yang mengisi 2 orang guru dan satu orang petugas tata usaha, bila tidak ada petugas tata usaha diminta yang mengisi 3 orang guru.

Teknik Pengumpulan Data dan Teknik Analisis Data

Penelitian ini menggunakan teknik pengumpulan data dengan angket yang dibagikan kepada guru dan petugas tata usaha sekolah. Angket dibuat dengan menggunakan kuisioner jawaban tertutup. Responden cukup memilih salah satu jawaban yang disediakan pada setiap soalnya dengan melingkari salah satu huruf pada awal alternatif jawaban yang dianggap sesuai (a, b, c, d dan e). Jawaban responden yang didapat kemudian diberi skor yakni ( $a=1, b=2, c=3, d=4$ dan $e=5)$. Kemudian diadakan perhitungan pada masing-masing sekolah dan seluruh SD/ MI di Kecamatan Depok.

Untuk mengetahui handal tidaknya dilakukan perhitungan data penelitian dengan uji teknik Cronbach. Menurut Arikunto (2010, pp.238-239). Hasil uji reliabilitas butir isntrumen pada masing-masing variabel dengan menggunakan bantuan program SPSS 16 ( Statistical Product and Service Solution Versi 16 ) diperoleh angka, pada penerapan kepemimpinan transformasional kepala sekolah koefisien Cronbach's Alpha menunjukkan angka 0,961 berarti reliabel dengan tingkat korelasi sangat tinggi. Pelaksanaan manajemen berbasis sekolah koefisien Cronbach's Alpha menunjukkan angka 0,862 berarti reliabel dengan tingkat korelasi sangat tinggi. Pelaksanaan tugas tata usaha koefisien Cronbach's Alpha menunjukkan angka 0,939 berarti reliabel dengan tingkat korelasi sangat tinggi. Dan kualitas pendidikan SD/ MI koefisien Cronbach's Alpha menunjukkan angka 0,864 berarti reliabel dengan tingkat korelasi sangat tinggi, maka dapat disimpulkan bahwa alat ukur dalam penelitian ini reliabel, salah satu syarat terpenuhi untuk digunakan sebagai alat pengukuran.

\section{Hasil Penelitian dan Pembahasan}

Pengaruh Kepemimpinan Transformasional Kepala Sekolah, Pelaksanaan Manajemen Berbasis Sekolah, Pelaksanaan Tugas Tata Usaha Terhadap Kualitas Pendidikan SD/MI.

Menurut Usman (2011, p.513), kualitas layanan pendidikan meliputi kualitas input, kualitas proses dan kualitas output. Hubungan dan pengaruh kepemimpinan transformasional kepala sekolah, pelaksa- 
naan manajemen berbasis sekolah, dan pelaksanaan tugas tata usaha sekolah secara bersama-sama memiliki kontribusi yang besar terhadap kualitas layanan pendidikan SD/MI. Secara parsial variabel-variabel di atas ada menunjukkan hubungan dan pengaruh yang nyata, yakni pada variabel pelaksanaan tugas tata usaha di sekolah, bila semuanya dilaksanakan atau diterapkan secara simultan dan terorganisir dan profesional tentu akan memiliki pengaruh yang sangat kuat.

Tabel berikut deskripsi hasil penelitian kualitas pendidikan di Kecamatan Depok Sleman tahun 2014.

\section{Tabel 1. Frekuensi Data Variabel Kualitas} Pendidikan

\begin{tabular}{ccccc}
\hline No & Kelas Interval & $\begin{array}{c}\text { Freku- } \\
\text { ensi }\end{array}$ & $\begin{array}{c}\text { Persen- } \\
\text { tase }\end{array}$ & Kategori \\
\hline 1 & $\leq 102,95$ & 1 & $2 \%$ & $\begin{array}{c}\text { Sangat } \\
\text { Rendah }\end{array}$ \\
2 & $102,95-111,93$ & 12 & $28 \%$ & Rendah \\
3 & $111,93-120,91$ & 18 & $42 \%$ & Sedang \\
4 & $120,91-129,89$ & 8 & $19 \%$ & Tinggi \\
5 & $\geq 129,89$ & 4 & $9 \%$ & Sangat \\
& & & & Tinggi \\
\hline & Jumlah & 43 & $100 \%$ & \\
\hline
\end{tabular}

Dari data yang terkumpul setelah dianalisis, bahwa kualitas pendidikan di SD/MI di kecamatan Depok kabupaten Sleman sebanyak 4 sekolah atau sekitar 9\% termasuk kategori sangat tinggi, 19\% dalam kategori tinggi, dan sisanya $42 \%$ dalam kategori sedang serta $28 \%$ dalam kategori rendah dan $2 \%$ dalam kategori sangat rendah.

Pihak sekolah harus terus berupaya untuk mengevaluasi dan memperbaiki variabel-variabel tersebut agar kualitas layanan pendidikan di sekolah semakin meningkat sehingga terwujud lembaga sekolah yang terpercaya, layanan pendidikan di SD/MI semakin baik yang dapat memenuhi keingginan dan harapan semua pihak baik stake holders internal dan eksternal maupun pelanggan pendidikan yaitu para peserta didik, orang tua siswa dan masyarakat maupun pemerintah.
Tabel 2. Hasil Analisis Adjusted R Square Model Summary

\begin{tabular}{ccccc}
\hline Model & $\mathrm{R}$ & $\begin{array}{c}\mathrm{R} \\
\text { Square }\end{array}$ & $\begin{array}{c}\text { Adjusted } \\
\text { Square }\end{array}$ & $\begin{array}{c}\text { Std. Error of } \\
\text { the Estimate }\end{array}$ \\
\hline 1 & $0,774^{\mathrm{a}}$ & 0,599 & 0,568 & 5,902
\end{tabular}

a. Predictors: (Constant), Pelaksana Tugas Tata Usaha, Kepemimpinan Transformasional Kepala Sekolah, Pelaksanaan Manajemen Berbasis Sekolah

b. Dependent Variable: Kualitas Pendidikan

Hasil penelitian ini menunjukkan bahwa kepemimpinan transformasional kepala sekolah, pelaksanaan manajemen berbasis sekolah, dan pelaksanaan tugas tata usaha sekolah memiliki hubungan secara bersama-sama dalam hitungan statistik sebesar $74,4 \%$ dengan kualitas pendidikan. Hubungan tersebut cukup kuat. Artinya, semakin bagus kepemimpinan transformasional kepala sekolah, pelaksanaan manajemen berbasis sekolah, dan pelaksanaan tugas tata usaha sekolah secara bersama-sama akan semakin bagus pula kualitas pendidikan. Adapun Adjusted $R$ Square menunjukkan angka 0,568 artinya bahwa $56,8 \%$ ada peningkatan bila kepemimpinan transformasional kepala sekolah, pelaksanaan manajemen berbasis sekolah, dan pelaksanaan tugas tata usaha sekolah diterapkan pada sutu organisasi/ lembaga memiliki kontribusi terhadap kualitas pendidikan. Sekolah harus terus-menerus berupaya dengan sungguh-sungguh terhadap faktor-faktor yang menyebabkan layanan pendidikan semakin baik dan meningkatkan untuk kemajuan pendidikan.

Pengaruh Kepemimpinan Transformasional Kepala Sekolah terhadap kualitas Pendidikan SD/MI

Kepemimpinan Tranformasional Kepala Sekolah menurut Bass \& Aviola dalam (Komariah \& Triatna, 2010, p.79) dengan aspek yang digunakan adalah Idealiced influence, Idealiced consideration, Intellectual stimulation dan Inspiration motivation. Pada hakekatnya kepemimpinan transformasional (Transformational Leadership) merupakan suatu proses kepemimpinan dimana seseorang pemimpin berusaha mengembangkan komitmen pengikutnya dengan ber- 
bagi nilai-nilai organisasi dan visi organisasi. Keberhasilan sebuah organisasi lebih banyak dipengaruhi oleh kemampuan pemimpin dalam menjalankan roda organisasi. Pemimpin yang transformasional lebih menggunakan sistem pendekatan untuk mencapai kondisi yang diinginkan dan pemecahan masalah. Kepemimpinan transformasional sangat cocok diterapkan pada saat ini dan untuk masa yang akan datang. Hal ini disebabkan karena kepe-mimpinan transformasional merupakan model kepemimpinan dimana pemimpin berani melakukan perubahan menuju tingkat produktivitas organisasi yang tinggi.

Dalam aplikasi pada satuan pendidikan, kepala sekolah adalah pemimpin yang mengatur dan merencanakan apakah sekolah yang dipimpinnya akan mengalami kemajuan atau kemunduran. Kepala sekolah yang transformasional adalah kepala sekolah yang mampu menciptakan budaya organisasi yang positif, yaitu pemimpin yang mampu mengembangkan nilai-nilai: kerja keras, semangat kerja yang tinggi, disiplin, selalu berusaha meningkatkan mutu, dan memiliki nilai-nilai yang universal. Kepala sekolah yang transformasional dalam pelaksanaan tugasnya akan menunjukkan perannya sebagai seorang idealized influence, individual consideration, intelectual stimulation, dan sebagai seorang inspiration motivation. Apabila kepala sekolah telah melaksanakan masing-masing perannya sebagai pemimpin transformasional maka sekolah sebagai suatu organisasi akan mengalami perkembangan yang pada akhirnya mencapai kemajuan.

Hasil penelitian ini menunjukkan bahwa penerapan kepemimpinan transformasional memiliki hubungan yang kuat untuk meningkatkan kualitas pendidikan di tingakt SD/MI, hasil uji regresi berganda menunjukkan nilai Standardized Coeefficients 0,174 . Berikut deskripsi pelaksanaan kepemimpinan transformasional kepala sekolah di Kecamatan Depok Sleman.

Dari data yang terkumpul telah dianalisis, bahwa penerapan kepemimpinan transformasional kepala sekolah di kecamatan Depok kabupaten Sleman 37\% da- lam kategori sangat tinggi, yaitu memperoleh skor antara 126,95-142,40 dan 37\% pula dengan skor antara 111,51 - 1126,95 dalam kategori sedang. Menurut para guru dan tenaga tata usaha sekolah, para kepala sekolah telah mengimplementasikan kepemimpinanan transformasional untuk meningkatkan kualitas dan kuantitas pelaksanaan organisi sekolah agar kualitas layanan pendidikan sesuai harapan konsumen baik para peserta didik, orang tua/ wali murid maupun pemerintah sehingga kualitas pendidikan di sekolah semakin meningkat dan lebih baik, namun ternyata hasil penelitian ini tidak menunjukan pengaruh yang signifikan.

Tabel 3. Frekuensi Data Variabel Penerapan Kepemimpinan Transformasional Kepala Sekolah.

\begin{tabular}{|c|c|c|c|c|}
\hline No & $\begin{array}{c}\text { Kelas } \\
\text { Interval }\end{array}$ & $\begin{array}{c}\text { Freku- } \\
\text { ensi }\end{array}$ & $\begin{array}{l}\text { Persen- } \\
\text { tase }\end{array}$ & Kategori \\
\hline 1 & $\leq 96,06$ & 4 & $9 \%$ & $\begin{array}{l}\text { Sangat } \\
\text { Rendah }\end{array}$ \\
\hline 2 & $\begin{array}{c}96,06-111,5 \\
1\end{array}$ & 7 & $16 \%$ & Rendah \\
\hline 3 & $\begin{array}{c}111,51-126 \\
95\end{array}$ & 16 & $37 \%$ & Sedang \\
\hline 4 & $\begin{array}{c}126,9-142,4 \\
0\end{array}$ & 16 & $37 \%$ & Tinggi \\
\hline 5 & $\geq 142,40$ & 0 & $0 \%$ & $\begin{array}{l}\text { Sangat } \\
\text { Tinggi }\end{array}$ \\
\hline & Jumlah & 43 & $199 \%$ & \\
\hline
\end{tabular}

Pengaruh Penerapan Manajemen Berbasis Sekolah terhadap kualitas Pendidikan SD/ MI

Wohlstetter dan Mohrman (Nurkolis, 2003, p.2-3), menyatakan bahwa Manajemen Berbasis Sekolah (MBS) merupakan suatu pendekatan untuk mendesain ulang organisasi sekolah dengan memberikan wewenang dan kekuasaan kepada partisipan sekolah pada tingkat lokal. Aspek dalam penelitian ini meliputi kewenangan organisasi sekolah, menggembangkan sumber daya sekolah dan keterlibatan stakeholder internal maupun eksternal sekolah.

Manajemen berbasis sekolah merupakan manajemen yang sangat tepat di- 
laksanakan di eraotonomi daerah seperti yang sekarang menjadi kebijakan pemerintah pusat. Sekolah tidak lagi dikendalikan secara penuh oleh pemerintah pusat. Pemerintah daerah pun memiliki kontribusi dan peran yang sangat penting dalam meningkatkan kualitas pendidikan SD/MI. Adanya manajemen berbasis sekolah sangat menguntungkan baik bagi sekolah maupun pemerintah sebagai penanggungjawab. Sekolah, dengan manajemen berbasis sekolah memiliki keleluasaan dalam menjalankan manajemen. Sekolah mampu mengukur kekuatannya sendiri dalam mencapai kualitas yang diinginkan atau yang telah ditetapkan. Dengan demikian penerapan manajemen berbasis sekolah sangat tepat dilaksanakan dalam rangka meningkatkan kualitas layanan pendidikan sesuai keingginan dan harapan semua pelanggan (peserta didik, orang tua siswa dan masyarakat).

Hasil penelitian ini menunjukkan bahwa penerapan manajemen berbasis sekolah memiliki hubungan yang kuat untuk meningkatkan kualitas pendidikan di tingkat SD/MI. Berikut deskripsi pelaksanaan manajemen berbasis sekolah di kecamatan Depok Sleman tahun 2014.

Tabel 4. Frekuensi Data Variabel Pelaksanaan Manajemen Berbasis Sekolah

\begin{tabular}{ccccc}
\hline No Kelas Interval & $\begin{array}{c}\text { Freku- } \\
\text { ensi }\end{array}$ & $\begin{array}{c}\text { Persen- } \\
\text { tase }\end{array}$ & Kategori \\
\hline 1 & $\leq 98,68$ & 5 & $12 \%$ & $\begin{array}{c}\text { Sangat } \\
\text { Rendah }\end{array}$ \\
2 & $98,68-110,79$ & 8 & $19 \%$ & $\begin{array}{c}\text { Rendah } \\
3\end{array}$ \\
$110,79-122,89$ & 13 & $30 \%$ & Sedang \\
4 & $122,89-135,00$ & 15 & $35 \%$ & Tinggi \\
5 & $\geq 135,00$ & 2 & $5 \%$ & Sangat \\
& & & & Tinggi \\
& Jumlah & 43 & $100 \%$ & \\
\hline
\end{tabular}

Dari data yang terkumpul telah dianalisis, bahwa pelaksanaan penerapan manajemen berbasis sekolah di kecamatan Depok kabupaten Sleman 5\% dalam kategori sangat tinggi, yaitu memperoleh skor $\geq 135$ dan 35\% dalam kategori tinggi dengan memperoleh skor antara 122,89 - 135.
Pengaruh Pelaksanaan Tugas Tata Usaha terhadap kualitas Pendidikan SD/MI

Pelaksanaan Tugas Administrasi Tata Usaha menutut Suharsimi Arikunto (2012, p.261). administrasi tata usaha adalah segenap proses kegiatan pengelolaan suratmenyurat yang dimulai dari menghimpun dan menerima, mencatat, mengelola, menggandakan, mengirim dan menyimpan semua bahan keterangan yang diperlukan oleh organisasi. Pelaksanaan tugas tata usaha merupakan salah satu komponen penunjang yang sangat penting dalam pelayanan pendidikan untuk mencapai pendidikan yang berkualitas di jenjang pendidikan manapun, terlebih jenjang SD/ MI. Pelayanan pelaksanaan tugas administrasi yang bagus dan terprogram secara rapi akan mempermudah para guru dalam melaksanakan pembelajaran di kelas dan mempermudah kepala sekolah dalam mengelola organisasi sekolah, baik yang berkaitan dengan kepentingan interen sekolah maupun kepentingan dengan organisasi kemitraanya, dinas pendidikan dan lembaga pemerintah lainya. Pengelolaan administrasi sekolah yang bagus akan mendorong sekolah untuk mencapai layanan pendidikan yang berkualitas tinggi.

Hasil penelitian ini menunjukkan bahwa pelaksanaan tugas tata usaha sekolah memiliki hubungan secara statistik 0,632 hal ini mengandung arti bahwa semakin bagus tugas tata usaha sekolah akan semakin bagus pula kualitas pendidikan. Adapun Adjusted $R$ Square menunjukkan angka 0,385 artinya bahwa pelaksanaan tugas tata usaha sekolah memiliki kontribusi yang nyata atau signifikan terhadap kualitas pendidikan sebesar 38,5\%. Sekolah seyogyanya menempatkan orang yang profesional untuk terus meningkatkan tugas tata usaha sekolah ini agar kualitas pendidikan terus meningkat.

Dari data yang terkumpul setelah dianalisis, bahwa pelaksanaan tugas tata usaha sekolah di SD/MI di kecamatan Depok kabupaten Sleman sebanyak 4 responden atau sekitar 9\% termasuk dalam kategori sangat tinggi dan $21 \%$ termasuk 
kategori tinggi dan $40 \%$ dalam kategori sedang, 21\% dalam kategori rendah dan 9\% dalam kategori sangat rendah.

Tabel 5. Frekuensi Data Variabel Pelaksanaan Tugas Tata Usaha Sekolah

\begin{tabular}{|c|c|c|c|c|}
\hline No & $\begin{array}{l}\text { Kelas } \\
\text { Interval }\end{array}$ & $\begin{array}{l}\text { Freku- } \\
\text { ensi }\end{array}$ & $\begin{array}{l}\text { Persen- } \\
\text { tase }\end{array}$ & Kategori \\
\hline 1 & $\leq 52,66$ & 4 & $9 \%$ & $\begin{array}{l}\text { Sangat } \\
\text { Rendah }\end{array}$ \\
\hline 2 & $\begin{array}{c}52,66-73,7 \\
5\end{array}$ & 9 & $21 \%$ & Rendah \\
\hline 3 & $\begin{array}{c}73,75-94,8 \\
5\end{array}$ & 17 & $40 \%$ & Sedang \\
\hline 4 & $\begin{array}{c}94,85-115 \\
95\end{array}$ & 9 & $21 \%$ & Tinggi \\
\hline 5 & $\geq 115,95$ & 4 & $9 \%$ & $\begin{array}{l}\text { Sangat } \\
\text { Tinggi }\end{array}$ \\
\hline & Jumlah & 43 & $100 \%$ & \\
\hline
\end{tabular}

Dengan demikian pihak sekolah dan pemerintah semestinya terus berbenah untuk meningkatkan kualitas pendidikan, Pelaksanaan tugas tata usaha seharusnya dibebankan pada petugas profesional dibidangya, tidak dibebankan pada guru sebagai tugas sampiran.

Bila secara umum sekolah dasar/madrasah ibtida'iyah di kecamatan Depok kabupaten Sleman saat ini belum memenuhi persyaratan minimal sesuai ketentuan yang telah ditetapkan pada Peraturan Menteri Pendidikan Nasional Republik Indonesia Nomor 24 Tahun 2008 tentang Standar Tenaga Administrasi Sekolah/Madrasah tersebut, maka pada tahun 2014 ini sangat perlu diupayakan keterlaksanaanya agar bisa memenuhi standar itu sesuai batas waktu yang ditetapkan dalam peraturan tersebut. Memang dalam peraturan memberi kelonggaran kepada penyelenggara sekolah/madrasah untuk menetapkan perangkapan jabatan apabila dikehendaki, hal ini harus menjadi bahan pertimbangan yang lebih seksama agar tidak berdampak pada menurunya kualitas layanan pendidikan. Jika kualitas layanan pendidikan menurun tentu berakibat pada menurunya prestasi peserta didik di sekolah, hal ini tentu bukan menjadi harapan kita semua.

\section{Simpulan dan Saran}

\section{Simpulan}

1. Melalui uji regresi linier berganda $(\hat{Y}=$ $\mathrm{X}_{1}+\mathrm{X}_{2}+\mathrm{X}_{3}$ ), pada pelaksanaan tugas tata usaha sekolah terbukti signifikan mempengaruhi kualitas pendidikan SD/MI di Kecamatan Depok Sleman, dengan kontribusi sebesar sebesar 56,8\%; Adjusted $\mathrm{R}^{2}=0,568 ; \mathrm{F}(3,39)=19,382 ; \mathrm{p}<0,05$. Hasil uji regresi juga menemukan bahwa persepsi guru tentang pelaksanaan tugas tata usaha sekolah $(\beta=0,477$; $\mathrm{p}<0,05)$ hanya variabel ini yang mempengaruhi kualitas pendidikan SD/MI.

2. Melalui uji regresi linier secara parsial $\left(\hat{Y}=X_{3}\right)$, pelaksanaan tugas tata usaha sekolah terbukti signifikan mempengaruhi kualitas pendidikan SD/MI di Kecamatan Depok. Besarnya kontribusi pengaruh pelaksanaan tugas tata usaha sekolah terhadap kualitas pendidikan SD/ MI sebesar $\beta=0,477 ; p<0,05$.

Implikasi

Di jenjang pendidikan dasar (SD/MI) khususnya sekolah di kecamatan Depok Sleman sangat perlu menerapkan dan meningkatkan model kepemimpinan transformasional, dengan hadirnya kepemimpinan transformasional ini mereka berani melakukan perubahan layanan pendidikan di sekolah menuju tingkat produktivitas organisasi yang tinggi. Kepala sekolah yang transformasional dalam pelaksanaan tugasnya akan menunjukkan perannya sebagai seorang yang bisa diteladani dan diidealkan serta selalu memberikan perhatian terhadap semua stafnya, selalu memberikan rangsangan untuk menerapkan cara-cara baru, memberikan motivasi yang diilhami dengan cita-cita yang tinggi hal ini sangat tepat sekali dalam mengantarkan sekolah yang didambakan pelangganya.

Dengan berjalanya pelaksanaan manajemen berbasis sekolah, pengambilan keputusan yang masih didominasi kepala sekolah bukan hal yang tepat, sebagai pemimpin yang transformasional, pemberdayaan warga sekolah merupakan hal yang 
seharusnya. Pelibatan semua stake holders sekolah dalam mengembangkan program peningkatan mutu pendidikan yang disesuaikan dengan kondisi dan potensi sekolah seyogyanya selalu dilakukan dengan musyawarah yang melibatkan semua stake holders sekolah.

Disamping itu kepala sekolah yang merupakan penanggungjawab langsung pada keberhasilan penyelenggaraan program di tingkat sekolah sebagai pucuk pimpinan seharusnya memperhatikan pembagian dan penyelesaian tugas bagi setiap anggota organisasi sesuai dengan jenis pekerjaannya. Kekurangan tenaga kependidikan yang dialami oleh tingkat pendidikan dasar (SD/MI) di kecamatan Depok sekarang ini tidak lah tepat bila beban tugas administrasi tata usaha sekolah ini dibebankan pada bapak dan ibu guru sebagai tugas sampiran. Mencermati hasil survai di kecamatan Depok Sleman ini, 91\% responden menyatakan pelaksanaan tugas tata usaha sekolah tidak dilakukan oleh petugas tata usaha khusus namun diampu oleh guru dan kepala sekolah, tidak dilakukan oleh tenaga tata usaha yang profesional hal ini dapat dipastikan mengganggu tugas utama guru yang pada akhirnya mengurangi kualitas pendidikan itu sendiri.

Pendidikan di sekolah senantiasa memerlukan upaya perbaikan dan peningkatan layanan sejalan dengan semakin tingginya kebutuhan dan tuntunan kehidupan masyarakat. Sekolah sebagai intitusi (lembaga) pendidikan, seharusnya merupakan wadah atau tempat dalam mensinkronkan antara proses pendidikan dan tuntutan masyarakat akan kebutuhan pendidikan. Kegiatan inti organisasi sekolah adalah mengelola sumber daya manusia yang diharapkan menghasilkan lulusan yang berkualitas sesuai dengan tuntutan kebutuhan masyarakat, serta pada gilirannya lulusan sekolah diharapkan dapat memberikan kontribusi pada pembangunan bangsa maka perlunya pendidikan yang berkualitas tinggi.

Pendidikan yang berkualitas adalah pendidikan yang dapat menghasilkan lu- lusan yang memiliki kemampuan dasar untuk belajar, menjadi dasar pembaharuan generasi bangsa dimasa mendatang dengan cara memberdayakan sumber-sumber pendidikan secara optimal melalui pembelajaran yang baik dan kondusif. Pendidikan yang berkualitas salah satu indikatornya adalah kemampuan lembaga dan sistem pendidikan dalam memberdayakan sumber-sumber pendidikan sesuai dengan tugas pokok dan fungsi sumberdaya yang dimilikinya untuk meningkatkan kualitas layanan yang sesuai dengan harapan atau tujuan pendidikan melalui proses pendidikan yang efektif.

Pada akhirnya kita tentu sependapat bahwa pendidikan yang berkualitas adalah pendidikan yang dapat menghasilkan lulusan yang berkualitas, yaitu lulusan yang memilki prestasi akademik dan non-akademik yang mampu menjadi pelopor pembaruan dan perubahan sehingga mampu menjawab berbagai tantangan dan permasalahan yang dihadapinya, baik di masa sekarang atau di masa yang akan datang (harapan bangsa).

Saran

Berdasar temuan penelitian maka disampaikan beberapa saran berikut ini:

1. Kepemimpinan transformasional harus dipahami dan diimplentasikan pada semua sekolah bila ingin memajukan organisasi sekolah.

2. Sejalan dengan pelaksanaan manajemen berbasis sekolah, kepala sekolah dapat memprakarsai dalam menjalin hubungan yang sinergis dengan steak holder internal maupun eksternal di sekolah untuk meningkatkan kualitas layanan pendidikan di sekolah.

3. Sejalan dengan diberinya kewenangan pada sekolah dalam mengurus rumah tangganya sendiri, sekolah dapat mengupayakan pemenuhan tenaga kependidikan yang memadahi, mengingat banyak pekerjaan tata usaha dikerjakan oleh guru.

Semua pihak yang menginginkan mutu pendidikan yang unggul hendaknya 
melakukan atau memperhatikan dengan seksama terhadap faktor-faktor yang akan meningkatkan kualitas layananan pendidikan termasuk kualitas input, proses dan output. Oleh karena itu, pemerintah sebagai pemegang kekuasaan yang melaksanakan kebijakan pendidikan hendaknya benar-benar mendampingi sekolah untuk meningkatkan kinerja sekolah dan mendorong untuk melaksanakan program MBS, memenuhi standar pendidik dan kependidikan di sekolah agar kualitas layanan pendidikan di sekolah semakin baik sehingga memenuhi harapan peserta didik, orangtua/wali murid, dan masyarakat.

DAFTAR PUSTAKA

Arikunto, S. (2010). Prosedur penelitian. Jakarta: Rineka Cipta.

(2012). Manajemen Pendidikan. Yogyakarta: Aditya Media.

Cheng, Y.C. (1996). School effectiveness $\mathcal{E}$ school-based management: A Mechanism for Development. The Falmer Press: London
Covey. S. (2007) The transformational leadership report http://www.trans formationalleadership.net/products /TransformationalLeadershipRepor t.pdf. diambil tanggal 19 Juni 2013

Komariah, A. \& Triatna, C. (2010). Visionary leadership-menuju sekolah efektif. Jakarta: Bumi Aksara.

Mulyasa, E. (2002). Manajemen berbasis sekolah. Bandung: Remaja Rosdakarya.

Nurkolis (2003). Manajemen berbasis sekolah. Jakarta: PT Grasindo

Sagala, S. (2011). Manajemen strategik dalam peningkatan mutu pendidikan. Bandung: Alfabeta.

Sallis, E. (1993). Total quality management in education. London: Kogan Page Educational Management Series.

Usman, H. (2011). Manajemen; Teori praktek dan riset pendidikan. Jakarta: Bumi Aksara, Cetakan ketiga. 